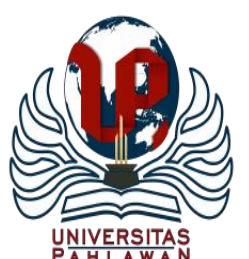

Jurnal Basicedu Volume 5 Nomor 1 Tahun 2021 Halaman 195-205

JURNAL BASICEDU

Research \&Learning in Elementary Education

https://jbasic.org/index.php/basicedu

\title{
Pengaruh Model Pembelajaran Inkuiri Terbimbing dengan Multi Representasi terhadap Keterampilan Proses Sains dan Penguasaan Konsep IPA
}

\author{
Kevin William Andri Siahaan', Sudirman T. P. Lumbangaol'², Juliaster Marbun³, \\ Ara Doni Nainggolan ${ }^{4}$, Jatodung Muslim Ritonga ${ }^{5}$, David Patria Barus ${ }^{6}$ \\ Prodi Pendidikan Kimia Fakultas Keguruan dan Ilmu Pendidikan, Universitas HKBP Nommensen \\ Pematangsiantar ${ }^{1}$, Prodi Pendidikan Fisika Fakultas Keguruan dan Ilmu Pendidikan, Universitas HKBP \\ Nommensen Pematangsiantar ${ }^{2,3,4,5,6}$ \\ Email: kevinsiahaan52@gmail.com ${ }^{1}$, dirmantogu@gmail.com ${ }^{2}$, astermarbun90@ gmail.com ${ }^{3}$, \\ aradoninainggolan@gmail.com ${ }^{4}$, muslimsiregar02@gmail.com ${ }^{5}, \underline{\text { davidpatria70@ gmail.com }}^{6}$
}

\begin{abstract}
Abstrak
Tujuan dari penelitian ini mengetahui model pengaruh pembelajaran inkuiri terbimbing dengan multi representasi terhadap keterampilan proses sains dan penguasaan konsep IPA siswa SMP Swasta Surya Pematangsiantar. Penelitian kuasi eksperimen ini menggunakan post-test only control group design dengan melibatkan siswa kelas IX yang dipilih secara simple random sampling. Kelas eksperimen menggunakan pembelajaran inkuri terbimbing dengan multi representasi dan kelas kontrol menggunakan pembelajaran inkuiri terbimbing. Hasil penelitian menunjukkan keterampilan proses sains siswa kelas eksperimen tidak berbeda dengan siswa kelas kontrol, sementara penguasaan konsep IPA siswa kelas eksperimen berbeda dari siswa kelas kontrol, dan keterampilan proses sains siswa berkorelasi positif dengan penguasaan konsep IPA.
\end{abstract} Kata kunci: model inkuiri terbimbing, multi representasi, keterampilan proses sains, penguasaan konsep IPA

\section{Abstract}

The aims of this study to determine the effect of guided model inquiry learning with multi representations on the mastery of science process skills and sciences concept IPA students of SMP Swasta Surya Pematangsiantar. This quasi experimental study use post-test only control group design involved $9^{\text {th }}$ grade students that selected by simple random sampling. Experimental class used guided inquiry learning with multi representation and control class used guided inquiry learning. The results showed that there are no differences science process skills between experimental class students and control class students, while the mastery of science concept experimental class students differences than students control class students, and science process skills students have positive correlation with science concept mastery.

Keywords: guided inquiry, multi representation, science process skills, science concept mastery

Copyright (c) 2021 Kevin William Andri Siahaan, Sudirman T. P. Lumbangaol, Juliaster Marbun, Ara Doni Nainggolan, Jatodung Muslim Ritonga, David Patria Barus

$\triangle$ Corresponding author :

Address :Jalan Perwira Lorong 23 Pematangsiantar ISSN 2580-3735 (Media Cetak)

Email :kevinsiahaan52@gmail.com $\quad$ ISSN 2580-1147 (Media Online)

Phone :0813623048

DOI $\quad:$ https://doi.org/10.31004/basicedu.v5i1.614 
196. Pengaruh Model Pembelajaran Inkuiri Terbimbing dengan Multi Representasi terhadap Keterampilan Proses Sains dan Penguasaan Konsep IPA - Kevin William Andri Siahaan, Sudirman T. P. Lumbangaol, Juliaster Marbun, Ara Doni Nainggolan, Jatodung Muslim Ritonga, David Patria Barus DOI: https://doi.org/10.31004/basicedu.v5i1.614

\section{PENDAHULUAN}

Ilmu Pengetahuan Alam (IPA) berkaitan dengan model pembelajaran dalam rangka mencapai tujuan cara mencari tahu tentang alam secara tersebut adalah dengan pembelajaran inkuiri terbimbing sistematis, sehingga IPA bukan hanya penguasa. Penggunaan inkuiri terbimbing disebabkan karena kumpulan pengetahuan yang berupa fakta-fakta, namun perkembangan intelektual siswa pada usia SMP konsep-konsep, atau prinsip-prinsip saja tetapi juga merupakan suatu proses penemuan (Depdiknas, 2006)IPA harus diajarkan dengan pembelajaran yang memungkinkan siswa mengembangkan kemampuan yang dimilikinya dan dapat membangun sendiri konsepnya. Dasar dari pembelajaran tersebut adalah pembelajaran konstruktivisme.

Pembelajaran akan lebih bermakna jika siswa diberi kesempatan untuk mengetahui dan terlibat secara aktif dalam menemukan konsep dari fenomena yang ada dari lingkungan dengan bimbingan guru. Salah satu menurut Piaget berada pada tingkatan operasional formal (Wood, dkk, 2011). Artinya, pada periode ini anak telah dapat berpikir logis, berpikir dengan pemikiran teoritis formal berdasarkan proposisi dan berhipotesis. Untuk mencapai tujuan tersebut diperlukan peran guru dalam pembelajaran.

Berdasarkan hasil observasi dan hasil wawancara yang telah dilakukan terhadap beberapa orang guru IPA SMP Swasta Surya Pematangsiantar diperoleh informasi bahwa pembelajaran yang selama ini dilakukan umumnya masih bersifat teacher centered approach. Pada beberapa kesempatan guru pernah melakukan inkuiri terbimbing. Informasi lainnya adalah keterampilan proses sains siswa masih rendah. Belum maksimalnya proses pembelajaran yang dilakukan seperti masih kurangnya praktikum atau percobaan untuk menguatkan konsep-konsep yang dipelajari menjadi salah satu penyebabnya. Ketuntasan pencapaian kompetensi siswa tentang beberapa konsep IPA juga masih belum maksimal. Masih banyak siswa yang mengalami kesulitan dalam menyelesaikan dan memahami konsepkonsep IPA.

Kesulitan siswa dalam pembelajaran inkuiri terbimbing antara lain merumuskan masalah dan hipotesis. Salah satu penyebabnya adalah siswa belum memahami demonstrasi yang disajikan oleh guru karena masih kurang bersifat multi representatif. Penyajian yang multi representatif dapat memudahkan siswa mengembangkan kemampuan multi representasinya yang menjadi kunci dalam pemecahan masalah matematis (Hwang dkk., 2007). Multi representasi diyakini dapat memperkecil kesulitan-kesulitan siswa dalam mempelajari konsep-konsep IPA misalnya pada materi Gaya dan Hukum Newton.

Berdasarkan hasil wawancara terhadap siswa diperoleh informasi bahwa IPA merupakan pelajaran yang dianggap paling sulit. Alasan yang mereka kemukakan adalah banyaknya hafalan konsep-konsep IPA, kajian dalam IPA bersifat kumulatif dan banyaknya rumus-rumus matematis. Mereka mengungkapkan bahwa banyak sekali informasi yang harus diterima dan diolah oleh 
197. Pengaruh Model Pembelajaran Inkuiri Terbimbing dengan Multi Representasi terhadap Keterampilan Proses Sains dan Penguasaan Konsep IPA - Kevin William Andri Siahaan, Sudirman T. P. Lumbangaol, Juliaster Marbun, Ara Doni Nainggolan, Jatodung Muslim Ritonga, David Patria Barus DOI: https://doi.org/10.31004/basicedu.v5i1.614

siswa. Pada dasarnya siswa harus dapat memahami konsep atau materi yang disajikan oleh guru maupun yang dipelajari oleh siswa. Gejala seperti ini telah dilaporkan oleh (Abdurrahmandkk,2011)

Secara umum ditemukan bahwa penguasaan konsep siswa rendah, kemampuan matematis lemah, dan siswa kurang mampu dalam mengkonversi satuan (Arief.et dkk, 2012). Sejalan dengan Ornek, Robinson \& Haugan (2008) kesulitan dalam belajar IPA disebabkan oleh banyak faktor, salah satunya dari diri siswa sendiri, seperti: (1) rendahnya motivasi dan ketertarikan belajar, (2) tidak mempelajari lagi materi yang telah diperoleh, (3) tidak membaca buku teks, (4) tidak mengerjakan pekerjaan rumah, (5) kurangnya pengalaman siswa sebagai pengetahuan awal, (6) rendahnya kemampuan matematika, serta (7) rendahnya kemampuan bahasa. Selain itu, rendahnya kemampuan verbal (menerjemahkan bahasa soal ke bahasa matematis), menggunakan skema, membuat strategi, dan membuat algoritma (Rusilowati, 2006).

Kendala-kendala lain yang dialami siswa adalah guru umumnya lebih banyak menggunakan representasi matematika dari pada representasirepresentasi yang lain. Berdasarkan itu siswa berpikiran bahwa rumus-rumus dan konsep-konsep tersebut harus dihafal (Yusuf dan Setiawan, 2009). Oleh karena itu, untuk mengoptimalkan model pembelajaran inkuiri terbimbing dan mengembangkan kemampuan siswa yang telah disebutkan maka dalam pembelajaran inkuiri terbimbing digunakan multi representasi.
Multi representasi berarti mempresentasi ulang konsep yang sama dengan format yang berbeda, di antaranya secara verbal, grafik dan mode angka (Waldrip dkk.,2006). Beberapa tujuan menggunakan multi representasi dalam proses pembelajaran disajikan berikut ini. Pertama, untuk memudahkan pemahaman konsep-konsep dan memecahkan masalah-masalah IPA yang dihadapi oleh siswa (Yusuf dan Setiawan, 2009). Kedua, untuk meningkatkan kemampuan kognitif siswa dalam mempelajari konsep IPA (Herawatidkk, 2013). Ketiga, untuk menuntut siswa mempresentasikan konsep yang dipelajarinya dalam berbagai bentuk, misalnya dalam bentuk verbal/teks, grafik, diagram, gambar maupun matematis sesuai dengan materi yang sedang dipelajari.

\section{METODE}

Penelitian metode kuantitatif ini dengan pendekatan kuasi eksperimen menggunakan posttest only control group design. Populasi dalam penelitian ini adalah siswa kelas VIII SMP Swasta Pematangsiantar. Dalam penelitian ini digunakan dua kelas penelitian yaitu kelas eksperimen dan kelas kontrol yang dipilih secara simple random sampling. Kelas eksperimen menggunakan pembelajaran inkuiri terbimbing dengan multi representasi dan kelas kontrol menggunakan pembelajaran inkuiri terbimbing. Instrumen dalam penelitian ini adalah: 1) instrumen keterlaksanaan pembelajaran yaitu silabus, Rencana Pelaksanaan Pembelajaran (RPP) dan Lembar Kerja Siswa (LKS), dan 2) instrumen tes tertulis keterampilan 
198. Pengaruh Model Pembelajaran Inkuiri Terbimbing dengan Multi Representasi terhadap Keterampilan Proses Sains dan Penguasaan Konsep IPA - Kevin William Andri Siahaan, Sudirman T. P. Lumbangaol, Juliaster Marbun, Ara Doni Nainggolan, Jatodung Muslim Ritonga, David Patria Barus DOI: https://doi.org/10.31004/basicedu.v5i1.614

proses sains dan penguasaan konsep IPA siswa. Pengumpulan data dilakukan dengan cara: 1) observasi terhadap instrumen perlakuan, dan 2) hasil post-test keterampilan proses sains dan penguasaan konsep IPA. Data dianalisis dengan menggunakan uji independent-sampel $t$ test dan pearson correlation.

\section{HASIL DAN PEMBAHASAN}

Hasil rata-rata observasi keterlaksanaan proses pembelajaran terhadap aktivitas guru menunjukkan persentase mencapai $93,43 \%$ dan rata-rata hasil observasi keterlaksanaan pembelajaran terhadap aktivitas siswa mencapai $87,41 \%$ dapat dilihat pada tabel 1

Tabel 1. Data Observasi Keterlaksanaan Proses Pembelajaran

\begin{tabular}{cc}
\hline $\begin{array}{c}\text { Keterlaksanaan Proses } \\
\text { Pembelajaran }\end{array}$ & $\%$ (Persentase) \\
\hline Aktivitas Guru & $93,43 \%$ \\
Aktivitas Siswa & $87,41 \%$ \\
\hline
\end{tabular}

Hasil analisis data penelitian menunjukkan bahwa nilai rata-rata keterampilan proses sains siswa pada kelas eksperimen adalah 78,94 dan pada kelas kontrol adalah 75,00 dengan nilai $t_{\text {hitung }}$ 1,235 dengan taraf signifikan 0,220 dapat di lihat tabel 2.

Tabel 2. Data Nilai Rata-rata Keterampilan Proses Sains

\begin{tabular}{lcc}
\hline \multicolumn{1}{c}{ Kelas } & Nilai rata-rata & $\boldsymbol{t}_{\text {hitung }}$ \\
\hline $\begin{array}{l}\text { Kelas } \\
\text { Eksperimen }\end{array}$ & 78,94 & 1,235 \\
Kelas Kontrol & 75,00 & $\begin{array}{c}\text { Taraf } \\
\text { signifikan }\end{array}$ \\
\hline
\end{tabular}

0,220

Hasil ini menunjukkan bahwa keterampilan proses sains siswa dengan pembelajaran inkuiri terbimbing dengan multi representasi tidak berbeda dengan keterampilan proses sains siswa pada pembelajaran inkuiri terbimbing. Nilai ratarata penguasaan konsep IPA siswa pada kelas eksperimen adalah 82,47 dan pada kelas kontrol adalah 77,83 dengan nilai thitung 2,350 dengan taraf signifikan 0,021. Hasil ini menunjukkan bahwa penguasaan konsep IPA siswa kelas eksperimen berbeda dengan kelas kontrol. Keterampilan proses sains siswa berkorelasi positif dengan penguasaan konsep IPA dengan koefisien korelasi sebesar 0,347 dengan signifikansi 0,017 dapat dilihat pada tabel 3 .

Tabel 3. Data Rata-rata Penguasaan Konsep IPA

\begin{tabular}{llll}
\hline \multicolumn{1}{c}{ Kelas } & \multicolumn{1}{c}{$\begin{array}{c}\text { Nilai } \\
\text { Rata-rata }\end{array}$} & $\boldsymbol{t}_{\text {hitung }}$ & $\begin{array}{c}\text { Taraf } \\
\text { Signifikan }\end{array}$ \\
\hline $\begin{array}{l}\text { Kelas } \\
\text { Eksperimen }\end{array}$ & 82,47 & 2,350 & 0,021 \\
$\begin{array}{l}\text { Kelas } \\
\text { Kontrol }\end{array}$ & 77,83 & 2,350 & 0,021 \\
\hline
\end{tabular}

Hal ini menunjukkan bahwa terdapat hubungan yang positif antara keterampilan proses sains dan penguasaan konsep IPA siswa.

\section{PEMBAHASAN}

Pengujian hipotesis yang telah dilakukan menunjukkan hasil sebagai berikut. Pertama, pengujian hipotesis yang telah dilakukan menunjukkan hasil keterampilan proses sains siswa yang belajar menggunakan pembelajaran 
199. Pengaruh Model Pembelajaran Inkuiri Terbimbing dengan Multi Representasi terhadap Keterampilan Proses Sains dan Penguasaan Konsep IPA - Kevin William Andri Siahaan, Sudirman T. P. Lumbangaol, Juliaster Marbun, Ara Doni Nainggolan, Jatodung Muslim Ritonga, David Patria Barus DOI: https://doi.org/10.31004/basicedu.v5i1.614

inkuiri terbimbing dengan multi representasi tidak berbeda secara signifikan atau sama dengan siswa yang belajar dengan pembelajaran inkuiri terbimbing. Penyebabnya adalah karena kedua kelompok menggunakan model pembelajaran inkuiri terbimbing yang pada dasarnya memperoleh pengetahuan dengan cara melakukan kerja ilmiah terlebih dahulu sehingga siswa dapat lebih memahami keterampilan proses sains karena terintegrasi di dalam sintaks pembelajarannya. Pembelajaran inkuiri memiliki hubungan dengan indikator-indikator dalam keterampilan proses sains. Persamaan antara sintaks pembelajaran inkuiri terbimbing dengan indikator-indikator keterampilan proses sains yang dapat mengakibatkan tidak adanya perbedaan keterampilan proses sains siswa antara kelompok eksperimen dan kelompok kontrol.

Proses pembelajaran inkuiri memberi kesempatan kepada siswa untuk memiliki pengalaman belajar yang nyata dan aktif sehingga siswa terlatih dalam memecahkan masalah sekaligus membuat keputusan. (Simsek dan Kabapinar, 2010) pembelajaran sains dengan inkuiri memberi pengaruh nyata terhadap keterampilan proses sains siswa. Pembelajaran inkuiri lebih efektif dalam membantu siswa untuk memperoleh keterampilan proses sains karena siswa terlibat secara langsung seperti mengajukan pertanyaan dalam suasana informal, menguji hipotesis, dan membangun penjelasan. Kegiatankegiatan yang berlangsung selama pembelajaran inkuiri tidak hanya memberikan kontribusi terhadap keterampilan penyelidikan ilmiah tetapi juga pemahaman siswa terhadap konsep sains.

Beberapa hasil penelitian telah menunjukkan kelebihan inkuiri dalam pembelajaran sains. (Sabahiyah dkk, 2013) menunjukkan bahwa terdapat pengaruh model pembelajaran inkuiri terbimbing terhadap peningkatan keterampilan proses sains dan penguasaan konsep IPA. (Rokhmatika dkk, 2012) menyimpulkan bahwa model pembelajaran inkuiri terbimbing dipadu kooperatif jigsaw berpengaruh terhadap keterampilan proses sains tetapi kemampuan akademik tidak berpengaruh terhadap keterampilan proses sains.

Berdasarkan hasil analisis dalam penelitian dan hasil penelitian terdahulu, dapat disimpulkan bahwa model pembelajaran inkuiri terbimbing dapat meningkatkan keterampilan proses sains siswa dikarenakan mengikuti langkah-langkah pembelajaran inkuiri terbimbing. Melalui kegiatan keilmiahan tersebut akan memberikan kesempatan lebih banyak kepada siswa untuk mencari dan menemukan sendiri fakta, konsep, dan prinsip melalui pengalaman secara langsung sehingga proses pembelajaran menjadi lebih optimal.

Berdasarkan pengalaman proses belajar siswa tersebut, pembelajaran inkuiri terbimbing lebih menekankan pada keaktifan belajar siswa untuk menumbuhkan kemampuan siswa dalam menggunakan keterampilan proses sains dengan merumuskan pertanyaan yang mengarah pada kegiatan penyelidikan, menyusun hipotesis, melakukan penelitian, mengumpulkan dan mengolah data, dan mengkomunikasikan hasil 
200. Pengaruh Model Pembelajaran Inkuiri Terbimbing dengan Multi Representasi terhadap Keterampilan Proses Sains dan Penguasaan Konsep IPA - Kevin William Andri Siahaan, Sudirman T. P. Lumbangaol, Juliaster Marbun, Ara Doni Nainggolan, Jatodung Muslim Ritonga, David Patria Barus DOI: https://doi.org/10.31004/basicedu.v5i1.614

temuannya dalam proses pembelajaran. Kegiatan inkuiri sangat penting karena dapat mengoptimalkan keterlibatan pengalaman langsung siswa dalam proses pembelajaran.

Pembelajaran dengan multi representasi tidak terlalu memberi pengaruh terhadap keterampilan proses sains keterampilan proses sains. Salah satu penyebabnya adalah karena belum maksimalnya penggunaan multi representasi dalam pembelajaran inkuiri terbimbing oleh siswa dan guru yang lebih banyak peran dalam menggunakan multi representasi. Selain itu, multi representasi lebih cenderung kepada bagaimana menyajikan konsep-konsep dalam berbagai bentuk supaya lebih mudah dipahami oleh siswa.

Model pembelajaran inkuiri terbimbing dengan multi representasi dan pembelajaran inkuiri terbimbing dapat membantu siswa memperoleh keterampilan-keterampilan proses sains karena setiap siswa melakukan kegiatan-kegiatan ilmiah. Keterampilan tersebut dapat dilatih secara terus menerus sehingga setiap siswa pada akhirnya dapat melakukan kegiatan keilmiahannya. Dalam pembelajaran inkuiri terbimbing dengan multi representasi siswa dapat merepresentasikan konsep atau materi yang dipelajarinya dalam berbagai cara atau bentuk untuk lebih memahamkan siswa akan konsep atau materi yang dipelajari.

Kedua, pengujian hipotesis yang telah dilakukan menunjukkan perbedaan yang signifikan antara penguasaan konsep IPA siswa yang belajar menggunakan pembelajaran inkuiri terbimbing dengan multi representasi dan siswa yang belajar dengan pembelajaran inkuiri terbimbing. Perbedaan ini disebabkan karena dalam pembelajaran inkuiri terbimbing dengan multi representasi siswa mendapat penjelasan dari materi yang telah dipelajari dengan berbagai representasi untuk lebih memudahkan siswa dalam memahami materi yang dipelajari dalam berbagai cara atau bentuk.

Penguasaan konsep sangat penting dimiliki oleh setiap siswa setelah melakukan pembelajaran karena dapat digunakan untuk menyelesaikan suatu permasalahan yang berkaitan dengan konsep yang dimiliki oleh siswa. Penguasaan konsep oleh siswa tidak hanya pada mengenal sebuah konsep tetapi siswa dapat menghubungkan antara satu konsep dengan konsep lainnya dalam berbagai situasi. Penguasaan konsep IPA siswa yang dibelajarkan dengan pembelajaran inkuiri terbimbing dengan multi representasi lebih tinggi dari pada siswa yang dibelajarkan dengan pembelajaran inkuiri terbimbing.

Beberapa hasil penelitian sebelumnya menunjukkan pengaruh pembelajaran inkuiri terbimbing terhadap penguasaan konsep siswa. (Praptiwi dkk, 2012) menunjukkan bahwa penerapan model pembelajaran inkuiri terbimbing berbantuan my own dictionary efektif untuk meningkatkan penguasaan konsep dan unjuk kerja siswa. (Puspawati dkk,2013) dalam penelitiannya menunjukkan bahwa pemahaman konsep IPA siswa pada pembelajaran model pembelajaran inkuiri terbimbing berbatuan media konkret lebih tinggi dari pada siswa yang mengikuti pembelajaran dengan model pembelajaran 
201. Pengaruh Model Pembelajaran Inkuiri Terbimbing dengan Multi Representasi terhadap Keterampilan Proses Sains dan Penguasaan Konsep IPA - Kevin William Andri Siahaan, Sudirman T. P. Lumbangaol, Juliaster Marbun, Ara Doni Nainggolan, Jatodung Muslim Ritonga, David Patria Barus DOI: https://doi.org/10.31004/basicedu.v5i1.614

langsung. (Dewi dkk, 2013) menunjukkan bahwa sikap ilmiah dan hasil belajar IPA yang belajar dengan model pembelajaran inkuiri terbimbing lebih baik daripada kelompok siswa yang belajar dengan model pembelajaran konvensional. (Wijayanti dkk, 2010) mengungkapkan bahwa pembelajaran inkuiri terbimbing pada pokok bahasan cahaya mampu mengatasi kesulitan belajar siswa yang berdampak pada peningkatan hasil belajar siswa.

Hasil penelitian lainnnya menunjukkan bahwa pengaruh pembelajaran multi representasi terhadap hasil belajar. Mahardika dkk, 2012) dari hasil penelitiannya dapat disimpulkan bahwa pembelajaran dengan model inkuiri dapat meningkatkan kemampuan representasi verbal, matematis dan hasil belajar siswa. Hasil penelitian menyimpulkan bahwa prestasi belajar siswa dengan pembelajaran multipel representasi pada materi laju reaksi lebih tinggi daripada pembelajaran konvensional.(Herawati dkk, 2013). Pendekatan multi representasi yang digunakan dalam pembelajaran konseptual interaktif memiliki efektivitas yang tergolong tinggi dalam menanamkan konsep-konsep yang tercakup dalam materi Teorema Usaha dan Energi. Hasil penelitian dapat disimpulkan bahwa proses pembelajaran fisika kuantum pada kelas eksperimen telah berhasil melibatkan mahasiswa dalam berbagai pengalaman belajar yang memberikan kesempatan kepada mereka mempelajari konsep-konsep fisika kuantum melalui penyajian dan pengembangan berbagai format representasi (Abdurrahman dkk, 2011). Format-format representasi tersebut adalah representasi verbal baik oral (melalui diskusi dan presentasi) maupun tulisan (menulis sejumlah argumentasi tentang hasil kajian konsep fisika kuantum), representasi visual baik yang bersifat statik (gambar, grafik, tabel, atau diagram) maupun yang bersifat dinamik (simulasi dan animasi gejala kuantum), representasi simbolik dan matematika, serta aktivitas laboratorium virtual.

(Ainsworth, 2006) menyatakan bahwa penggunaan multipel representasi untuk melengkapi informasi ketika masing-masing representasi dalam sistem menyajikan informasi yang berbeda. (Bahri, 2013), penggunaan multi representasi dapat memudahkan siswa mengidentifikasi dan mendeskripsikan suatu masalah secara lebih utuh dan menyelesaikannya dengan pemahaman, nalar dan argumentasi yang lebih kokoh. (Waldrip dkk, 2006) menyimpulkan bahwa untuk menumbuh kembangkan pembelajaran sains di sekolah siswa membutuhkan pemahaman dan menghubungkan representasi verbal, visual, dan matematika dalam mengembangkan pengetahuan konsep dan proses ilmiah. Guru IPA idealnya memiliki kemampuan argumentasi ilmiah dan dapat menyampaikan materi IPA dalam berbagai bentuk representasi (multiple representations).

Berdasarkan uraian di atas dapat dikatakan bahwa model pembelajaran inkuiri terbimbing dengan multi representasi memberi pengaruh yang signifikan terhadap penguasaan konsep IPA bila dibandingkan dengan pembelajaran inkuiri terbimbing sehingga siswa dapat lebih memahami 
202. Pengaruh Model Pembelajaran Inkuiri Terbimbing dengan Multi Representasi terhadap Keterampilan Proses Sains dan Penguasaan Konsep IPA - Kevin William Andri Siahaan, Sudirman T. P. Lumbangaol, Juliaster Marbun, Ara Doni Nainggolan, Jatodung Muslim Ritonga, David Patria Barus DOI: https://doi.org/10.31004/basicedu.v5i1.614

konsep IPA dalam berbagai situasi yang dihadapinya dalam kehidupan sehari-hari.

Ketiga, berdasarkan hasil analisis hubungan keterampilan proses sains dan penguasaan konsep IPA diperoleh hasil bahwa keterampilan proses sains berkorelasi positif dengan penguasaan konsep IPA. Artinya, perubahan yang terjadi pada keterampilan proses sains akan diikuti secara positif oleh perubahan penguasaan konsep IPA siswa. Hasil penelitian yang dilakukan dapat disimpulkan bahwa penerapan pembelajaran dengan pendekatan keterampilan proses pada materi Kalor dapat meningkatkan hasil belajar dan kemampuan berpikir kreatif siswa (Rahayu dkk, 2011). (Wahyudi dan Supardi, 2013) menyimpulkan bahwa penerapan pembelajaran inkuiri terbimbing dengan melatih keterampilan proses sains dapat meningkatkan hasil belajar siswa pada materi Kalor. (Haryono, 2006) mengungkapkan dari hasil penelitiannya yaitu: 1) model pembelajaran berbasis peningkatan keterampilan proses sains adalah bentuk pembelajaran yang mengintegrasikan keterampilan proses sains ke dalam rangkaian proses belajar mengajar guna mengarahkan siswa pada proses konstruksi pengetahuan secara mandiri, 2) model pembelajaran berbasis keterampilan proses sains terbukti cukup efektif dalam meningkatkan kemampuan proses sains siswa sekaligus pencapaian hasil belajarnya secara keseluruhan. Hasil belajar kognitif, psikomotorik, dan sikap pada pembelajaran sains dapat ditingkatkan dengan pendekatan keterampilan proses (Subagyo, 2009).

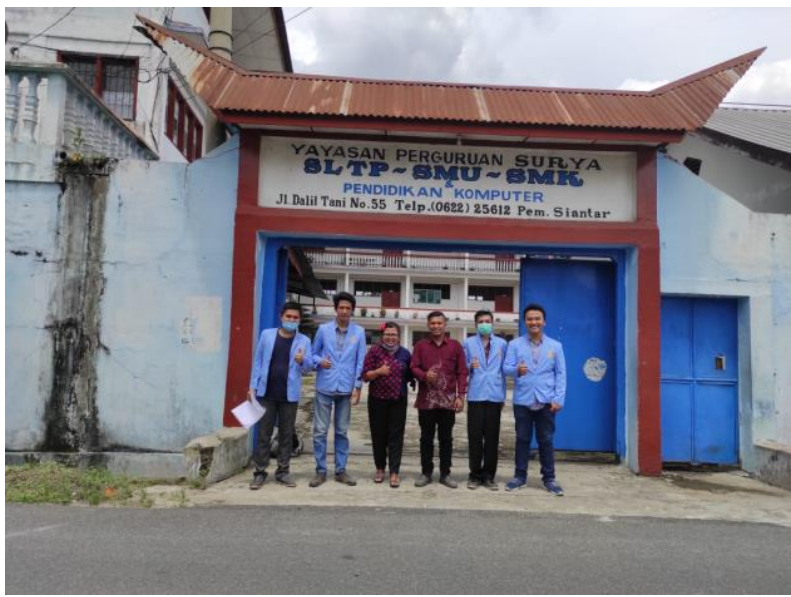

Gambar 1. Dokumentasi Bersama Kepala Sekolah SMP Sw Surya Pematangsiantar mengenai Pengaruh Model Inkuiri Terbimbing dengan Multi Representasi

Keterampilan proses sains memiliki pengaruh dalam pendidikan sains karena membantu siswa untuk mengembangkan keterampilan intelektual, keterampilan manual dan keterampilan sosial (Rustaman, 2005). Keterampilan proses sains berfungsi sebagai kompetensi yang efektif untuk mempelajari ilmu pengetahuan dan teknologi, pemecahan masalah, pengembangan individu dan sosial (Akinbobola dan Afolabi, 2010). Sudah sepatutnya para pendidik mengembangkan keterampilan proses sains siswa sebagai pendukung dalam mengembangkan penguasaan konsep IPA sehingga pada akhirnya akan memberikan hasil belajar yang terbaik.

\section{KESIMPULAN}

Berdasarkan hasil penelitian dan hasil uji hipotesis yang telah dilakukan, maka dapat dikemukakan beberapa simpulan. Keterampilan 
203. Pengaruh Model Pembelajaran Inkuiri Terbimbing dengan Multi Representasi terhadap Keterampilan Proses Sains dan Penguasaan Konsep IPA - Kevin William Andri Siahaan, Sudirman T. P. Lumbangaol, Juliaster Marbun, Ara Doni Nainggolan, Jatodung Muslim Ritonga, David Patria Barus DOI: https://doi.org/10.31004/basicedu.v5i1.614

proses sains siswa yang dibelajarkan menggunakan inkuiri terbimbing dengan multi representasi tidak berbeda secara signifikan dengan keterampilan proses sains siswa yang dibelajarkan dengan pembelajaran inkuiri terbimbing. Penguasaan konsep IPA siswa yang dibelajarkan menggunakan inkuiri terbimbing dengan multi representasi berbeda secara signifikan daripada penguasaan konsep IPA siswa yang dibelajarkan dengan pembelajaran inkuiri terbimbing. Terdapat hubungan antara keterampilan proses sains dan penguasaan konsep IPA siswa dalam pembelajaran inkuiri terbimbing dengan multi representasi.

\section{SARAN}

Berdasarkan hasil penelitian maka dapat dikemukakan beberapa saran, yaitu agar guru membiasakan membelajarkan siswa dengan multi representasi yang terintegrasi dalam pembelajaran inkuiri terbimbing sehingga siswa akan lebih mudah saat mengikuti pembelajaran. Guru juga harus meninggalkan penggunaan LKS individu karena dapat menyebabkan terjadinya pembelajaran yang individualis.

\section{DAFTAR RUJUKAN}

A.L.Rusli, A., \&Waldrip, B. (2015). Implementasi Pembelajaran Berbasis Multi RepresentasiUntuk Peningkatan Penguasaan Konsep Fisika Kuantum. JurnalCakrawalaPendidikan. https://doi.org/10.21831/cp.v1i1.4189

Akinbobola, A. O., \&Afolabi, F. (2010).Analysis of Science Process Skills in West African Senior Secondary School Certificate Physics.American-Eurasian Journal of Scientific Research.
Atasani, I. M., A.A.I.N, M., \& M., S. (2013). Pengaruhpenerapanmetodebermainperanterha dapkemampuanberbicarasiswaditinjaudarimi natberbahasa Indonesia siswakelas $\mathrm{V}$ gugus 1 Aikmel.e-Journal Program PascasarjanaUniversitasPendidikanGanesha Program StudiPendidikanDasar.

Bahri, S.

(2012).Penggunaanmultiplerepresetasidanarg umentasiilmiahdalampembelajaranfisika.Jurn alSerambillmu.

Depdiknas. 2006. Model Silabus dan Rencana Pelaksanaan Pembelajaran Mata Pelajaran Ilmu Pengetahuan Alam. Jakarta: Badan Standar Nasional Pendidikan.

Dewi, N. L., Dantes, N.,\& Sadia, I. W. (2013). PengaruhModel Pembelajaran Inkuiri Terbimbing Terhadap Sikap Ilmiahdan Hasil Belajar IPA. e-Journal Program PascasarjanaUniversitasPendidikanGanesha

Efektivitas ModelPembelajaran Eksperimen Inkuiri Terbimbing Berbantuan My Own Dictionary Untuk Meningkatkan Penguasaan Konsepdan Unjuk Kerja Siswa SMP RSBI.(2012). Unnes Science Education Journal.https://doi.org/10.15294/usej.v1i2.88

Eksplorasi Kesulitan Belajar Siswa Pada Pokok Bahasan Cahayadan Upaya Peningkatan Hasil Belajar Melalui Pembelajaran Inkuiri Terbimbing.(2012). JurnalPendidikanFisika Indonesia.https://doi.org/10.15294/jpfi.v6i1.1 093

Haryono, H. (2006). Model pembelajaranberbasispeningkatanketerampila $\mathrm{n}$ proses sains. JurnalPendidikanDasar.

Herawati, R., Mulyani, S., \&Redjeki, T. (2013).Pembelajaran Kimia Berbasis Multiple Representasi Ditinjau Dari Kemampuan Awal Terhadap Prestasi Belajar Laju Reaksi Siswa SMA Negeri I Karanganyar Tahun Pelajaran 2011/2012.JurnalPendidikan Kimia.

Hwang, W. Y., Chen, N. S., Dung, J. J., \& Yang, Y. L. (2007).Multiple representation skills and creativity effects on mathematical problem solving using a multimedia 
204. Pengaruh Model Pembelajaran Inkuiri Terbimbing dengan Multi Representasi terhadap Keterampilan Proses Sains dan Penguasaan Konsep IPA - Kevin William Andri Siahaan, Sudirman T. P. Lumbangaol, Juliaster Marbun, Ara Doni Nainggolan, Jatodung Muslim Ritonga, David Patria Barus DOI: https://doi.org/10.31004/basicedu.v5i1.614

whiteboard system.In Educational Technology and Society.

Identifikasi Kesulitan Belajar Fisika Pada Siswa RSBI : Studi Kasusdi RSMABI Se Kota Semarang. (2012). UPEJ (Unnes Physics Education Journal). https://doi.org/10.15294/upej.v1i2.1354

Laila, Q. N., Tinggi, S., Tarbiyah, I., Al, N., \&Mojokerto, H. (2016). Pembelajaran Tematik Terpadu Pada Jenjang SD/MI. MODELING: Jurnal Program Studi PGMI.

Nilakusmawati, D. P. E., Sari, K., \&Puspawati, N. M. (2016). UpayaPeningkatanPenguasaan Guru SD DalamPenelitian. JurnalUdayanaMengabdi.

PendekatanMulti Representasi Dalam Pembelajaran Usaha-Eenergi dan Dampak Terhadap Pemahaman Konsep Mahasiswa. (2012). Jurnal Pendidikan Fisika Indonesia. https://doi.org/10.15294/jpfi.v8i1.1988

Rahayu, E., H. Susanto, and D. Yulianti. 2011. 'Science Learning With Process Skills Approach To Improve Student Learning Outcomes And Creative Thinking Abilities'. Indonesian Journal of Physical Education.

Rokhmatika, S., \&Prayitno, B. A. (2012).Pengaruh Model InkuiriTerbimbingDipaduKooperatif Jigsaw TerhadapKeterampilan Proses the Influence of Guided Inquiry Combined Cooperative. PendidikanBiologi.

Rusilowati, A. (2007). Diagnosis KesulitanBelajarFisikaSiswa SD, SMP, dan SMA DenganTeknik General Diagnostic dan Analytic Diagnostic. Seminar Nasional Mipa 2007.

Rustaman, N. 2005. Strategi Belajar Mengajar Biologi (Cet. 1). Malang: Universitas Negeri Malang.

Şimşek, P., \& Kabapinar, F. (2010). The effects of inquiry-based learning on elementary students' conceptual understanding of matter, scientific process skills and science attitudes. Procedia - Social and Behavioral Sciences. https://doi.org/10.1016/j.sbspro.2010.03.170

Subagyo, Y., \& Marwoto, P. (2009). Untuk Meningkatkan Penguasaan Konsep. Jurnal
Pendidikan Fisika Indonesia (Indonesian Journal of Physics Education).

Virk, S. S., Clark, D. B., \&Sengupta, P. (2017).The design of disciplinarily-integrated games as multirepresentational systems.International Journal of Gaming and Computer-Mediated Simulations. https://doi.org/10.4018/IJGCMS.2017070103

Wahyudi, L. E., \& Supardi, Z. A. I. (2013). Penerapan Model Pembelajaran Inkuiri Terbimbing Pada Pokok Bahasan Kalor Untuk Melatihkan Keterampilan Proses Sains. Jipf.

Waldrip, B., Prain, V., \& Carolan, J. (2010). Using multi-modal representations to improve learning in junior secondary science. Research in Science Education. https://doi.org/10.1007/s11165-009-9157-6

Wood, K. C., Smith, H., \&Grossniklaus, D. (2001). P iaget' $s$ Stages of Cognitive Development. M.orey (Ed.), Emerging perspectives on learning, teaching and technology.

Yusuf, M., \&Setiawan, W. (2009).StudiKompetensiMultirepresentasiMa hasiswaPadaTopikElektrostatika.

JurnalPendidikanTeknologiInformasidanKo munikasi.

Yuwono, G., Mahardika, I., \&Gani, A. (2016).Pengaruh Model PembelajaranInkuiriTerbimbingTerhadapHas ilBelajarFisikaSiswa

(KemampuanRepresentasi Verbal, Gambar, Matematis, Dan Grafik) Di SMA. JurnalPembelajaranFisikaUniversitasJember 